\title{
Selective Media for Practical Isolations of Pythium spp. From Natural and Agricultural Environments
}

\author{
Tojo $\mathbf{M}^{*}$ \\ Graduate School of Life and Environmental Sciences, Osaka Prefecture University, Japan
}

Submission: June 09, 2017; Published: June 16, 2017

"Corresponding author: Tojo M, Graduate School of Life and Environmental Sciences, Osaka Prefecture University, Sakai, Osaka 599-8531, Japan, Email: tojo@plant.osakafu-u.ac.jp

Abstract

Two new Pythium selective media without using PCNB and pimaricin are developed. Their practical uses are introduced on isolation of the organs from natural and agricultural environments.

\section{Introduction}

Pythium spp. are distributed in wide range of environments in natural and agricultural sites [1]. Selective media is an effective and economic tool for quantitative and qualitative isolations of Pythium spp. from plant tissues, soil and water. PARP medium has been the most commonly used for isolation of Pythium spp. from soil [2]. The fungicide PCNB is an important component of this medium, but the commercial pesticide products are unavailable since hexachlorobenzene (HCB), which has carcinogenic activity, is present as an impurity in PCNB [3]. Moreover, pimaricin, which is also a necessary component of PARP is not commercially available in several countries including Japan due to the food sanitation law. Therefore efficient alternatives in Pythium selective media without using PCNB and pimaricin have been demanded. We previously modified PARP by replacing PCNB in the medium with fluazinam or miconazole, and nystatin with pimaricin [4]. The new media are NARF (nystatin+ampicillin+rifampicin+fluazinam) and NARM (nystatin+ampicillin+rifampicin+miconazole). NARF and NARM are comparable with PARP on yield of naturally occurring Pythium species from soil using the soil-dilution plating technique [4]. Since development of NARF and NARM, they were successfully used for isolations of Pythium spp. from many locations of natural and agricultural environments [5-7]. This review introduces practical techniques for isolation of Pythium spp. from natural and agricultural environments by using these new selective media.

\section{Media recipe}

\section{Basal medium of NARF and NARM}

17g of CMA (Becton Dickinson and Company, Franklin Lakes, NJ, USA)
$5 \mathrm{~g}$ of agar (Wako Pure Chemical Industries, Osaka, Japan) for isolation from plant tissue, or 23g of the agar for using soildilution plating

\section{Antibiotics for NARF}

50mg a.i. nystatin (Sigma-Aldrich, St. Louis, MO, USA) dissolved in $1 \mathrm{ml}$ ethanol

250mg a.i. ampicillin (Sigma-Aldrich) dissolved in 1ml DW

$10 \mathrm{mg}$ a.i. rifampicin (Sigma-Aldrich) dissolved in $1 \mathrm{ml}$ DMSO

$0.5 \mathrm{mg}$ a.i. of fluazinam (Froncide Wettable Powder ${ }^{\circledR}$, Nippon Soda, Tokyo, Japan) dissolved in $1 \mathrm{ml}$ of $0.1 \%$ sterile water agar

\section{Antibiotics for NARM}

10mg/L a.i. nystatin (Sigma-Aldrich) dissolved in $1 \mathrm{ml}$ ethanol 250mg/L a.i. ampicillin (Sigma-Aldrich) dissolved in 1ml DW 10mg/L a.i. rifampicin (Sigma-Aldrich) dissolved in 1ml DMSO $1 \mathrm{mg} / \mathrm{L}$ a.i. miconazole (Sigma-Aldrich) dissolved in $1 \mathrm{ml}$ DMSO

Each antibiotics was added to the basal medium after autoclaving and cooling to $50{ }^{\circ} \mathrm{C}$, mixed thoroughly with a magnetic stirrer, and $10 \mathrm{ml}$ of medium was poured into $9 \mathrm{~cm}$ diameter petri plates. If pimaricin is available, $5 \mathrm{mg} / \mathrm{L}$ a.i. pimaricin can be alternative to nystatin of NARF and NARM.

\section{ISOLATION FROM PLANT TISSUES}

Sections of diseased tissue are washed in tap water, air-dry, and incubate on NARF or NARM usually at $25{ }^{\circ} \mathrm{C}$ in darkness. Pythium mycelia that grew on the agar are transferred to CMA or water agar. 
A Van Tieghem cell method [8] is useful for purifying Pythium from bacterial contamination.

\section{Soil-dilution plating}

Approximately one $\mathrm{kg}$ of soil corrected from natural and agricultural environments is passed through a $4 \mathrm{~mm}$ sieve to remove large stones and debris. The $50 \mathrm{~g}$ of soil is placed in a $500 \mathrm{ml}$ flask containing $250 \mathrm{ml}$ of autoclaved $0.35 \%$ agar. The flask is shaken at $200 \mathrm{rpm}$ on a rotary shaker. From each soil dilution flask, a $10 \mathrm{ml}$ soil suspension is dispensed into a $500 \mathrm{ml}$ Erlenmeyer flask containing $490 \mathrm{ml}$ of sterile agar and shaken by hand. A $1 \mathrm{ml}$ aliquot of that soil dilution is plated onto each of 10 plates, and a bent glass rod is used to spread the aliquot over the plate. The plates are incubated for $24 \mathrm{~h}$ in the dark at $25{ }^{\circ} \mathrm{C}$. Following the incubation period, the surface of each plate is gently washed under a stream of water to remove the soil. The plates are further incubated for $24 \mathrm{hrs}$ and numbers of colonies of Pythium spp. are counted. Colonies of Pythium species can be distinguished by colony characteristics such as a fast growing rate, no cross walls in the young mycelium, and wide, highly branched hyphae. Colonies believed to be Pythium species are subcultured on CMA and confirm as Pythium by microscopic observation of the colonies. The density of Pythium spp. is expressed as the number of colonies per $\mathrm{g}$ of dry soil.

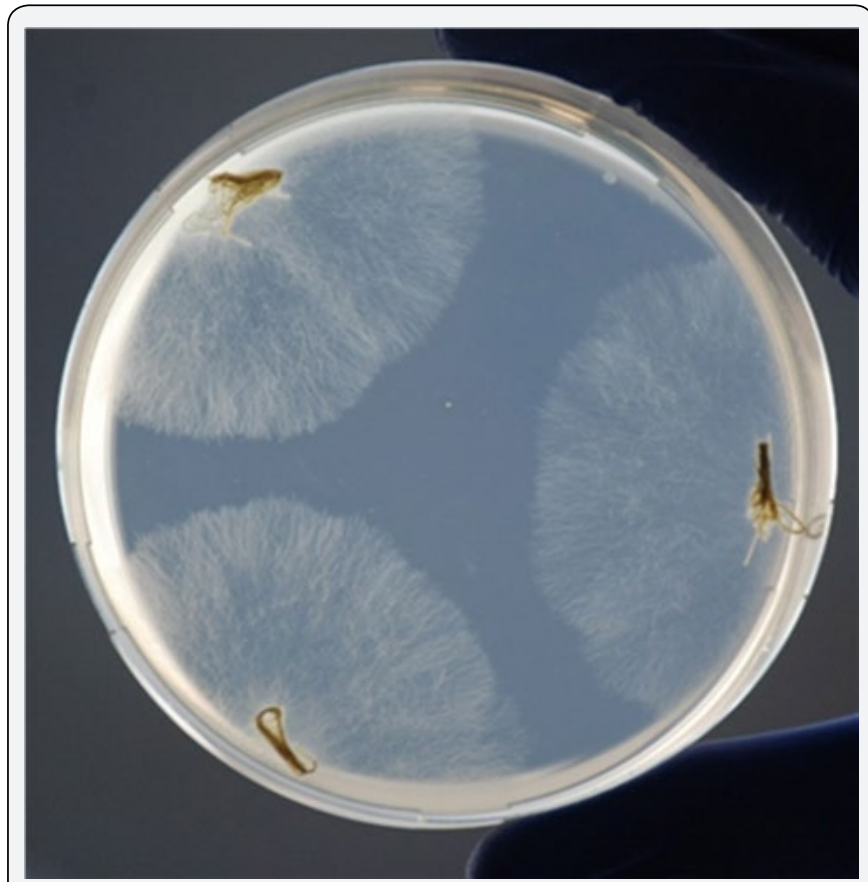

Figure 1: Colonies of Pythium aphanidermatum on NARM (nystatin+ampicillin+rifampicin+miconazole agar) in a 9cm Petri dish appeared from bent grass tissues after incubation for $18 \mathrm{~h}$ at $31{ }^{\circ} \mathrm{C}$.

\section{Advantages and disadvantages}

NARM is better or equivalent to PARP on Pythium growth and inhibition of non-pythiaceous microbes except for Fusarium spp. NARM is equivalent to PARP and is significantly better than NARF in having faster growth rates for isolates of Pythium (Figure 1). On the other hand, NARM promoted significantly higher growth of isolates of Fusarium spp. as compared to NARF and PARP. This is due to enhancement of miconazole on growth of Fusarium spp. in agar culture [9], although the Fusarium growth on NARM is still very slow $\left(<2 \mathrm{~mm} /\right.$ day at $\left.25^{\circ} \mathrm{C}\right)$. NARF can well inhibit growth of Fusarium spp. Both media can be used for isolation of Phytophthora and Phytopythium.

\section{Toxicity and cost}

Both fluazinam [10] and miconazole [11] have low toxicity to humans and the environments. Fluazinam is available as a common commercial fungicide and the cost for the $0.5 \mathrm{mg}$ needed to prepare 1 liter of NARF is minimal $(<\$ 0.01)$. Miconazole is available from Sigma-Aldrich at a cost of $\$ 0.04$ for the $1 \mathrm{mg}$ needed to prepare 1 liter of NARM. Including costs for the basal medium, the both media require less than $\$ 10$ to prepare 1 liter. For their practical uses, CMA (Becton Dickinson and Company) can cost lessly be alternate media such as a handmade cornmeal agar (HCMA) and V8 juice agar (V8JA). Our preliminary results demonstrated that NARF and NARM prepared with HCMA or V8JA are better to them prepared with the commercial CMA on Pythium hyphal growth.

\section{Acknowledgments}

This work was partially supported from the JSPS grant-in-aid for scientific research (No. 15K00626), and Geol Cosmetics Co. Ltd.

Selective media for practical isolations of Pythium spp. from natural and agricultural environments.

\section{References}

1. van der Plaats-Niterink AJ (1981) Monograph of the genus Pythium. Stud Mycol 21: 1-242.

2. Jeffers SN, Martin SB (1986) Comparison of two media selective for Phytophthora and Pythium species. Plant Dis 70(11): 1038-1043.

3. Choudhury H, Coleman J, Mink FL, De Rosa CT, Stara JF (1987) Health and environmental effects profile for pentachloronitrobenzene. Toxicol Industrial Health 3(1): 5-69.

4. Morita Y, Tojo M (2007) Modifications of PARP medium using fluazinam, miconazole, and nystatin for detection of Pythium spp. in soil. Plant Dis 91(12): 1591-1599.

5. Tojo M, Van West P, Hoshino T, Kida K, Fujii H, et al. (2012) Pythium polare, a new heterothallic Oomycete causing brown discoloration of Sanionia uncinata in the Arctic and Antarctic. Fungal Biol 116(7): 756768.

6. Bouket AC, Arzanlou M, Tojo M, Babai-Ahari A (2015) Pythium kandovanense sp. nov., a fungus-like eukaryotic microorganism (Stramenopila, Pythiales) isolated from snow covered ryegrass leaves. Int J Syst Evol Microbiol 65(8): 2500-2506.

7. Ueta S, Tojo M (2016) Pythium barbulae sp. nov. isolated from the moss, Barbula unguiculata; morphology, molecular phylogeny and pathogenicity. Mycoscience 57(1): 11-19.

8. Erwin DC, Ribeiro OK (1996) Phytophthora Diseases Worldwide. APS Press Am Phytopathol Soc, St. Paul USA, pp. 10-11.

9. Takehara T, Kuniyasu K, Mori M, Hagiwara H (2003) Use of a nitratenonutilizing mutant and selective media to examine population dynamics of Fusarium oxysporum f. sp. spinaciae in soil. Phytopathology 93(9): 1173-1181. 
10. Holligworth RM (2001) Inhibitors and un couplers of mitochondrial oxidative phosphorylation. In: Handbook of Pesticide Toxicology. $\left(2^{\text {nd }}\right.$ edn), Academic Press, New York, USA, pp. 1169-1262.
11. Schonwald S, Leviton IM (2004) Antifungal drugs. In: Medical Toxicology. ( $3^{\text {rd }}$ edn), Lippincott Williams \& Wilkins, Philadelphia, pp. 414-423.

\section{Your next submission with Juniper Publishers} will reach you the below assets

- Quality Editorial service

- Swift Peer Review

- Reprints availability

- E-prints Service

- Manuscript Podcast for convenient understanding

- Global attainment for your research

- Manuscript accessibility in different formats ( Pdf, E-pub, Full Text, Audio)

- Unceasing customer service

Track the below URL for one-step submission https://juniperpublishers.com/online-submission.php 